\title{
A comparative study on carbon stock in Sal (Shorea robusta) forest in two different ecological regions of Nepal
}

\author{
H. P. Pandey ${ }^{1}$ and M. Bhusal ${ }^{2}$
}

\begin{abstract}
Estimation of total biomass and carbon sequestration in any forest is crucial as it gives ecological and economic benefits through various environmental services. With an aim to quantify the carbon stock densities in the two different ecological regions-the Hills and the Terai, two Community Forests (CFs) having the dominance of Shorea robusta were selected from Gorkha (in the Hills) and Chitwan (in the Terai) districts for the purpose of the study. Systematic random sampling with $1 \%$ sampling intensity was used to collect necessary data. The total carbon stock in the CFs of the Hills and the Terai were found to be $234.54 \mathrm{t} \mathrm{ha}^{-1}$ and $479.29 \mathrm{t} \mathrm{ha}^{-1}$, respectively. The biomass carbon stock density in the CF of the Terai was found to be higher (384.20 tha-1) than the one in the Hills $\left(123.15 \mathrm{t} \mathrm{ha}^{-1}\right)$. Carbon densities of different carbon pools such as tree; sapling; leaf litter, grass and herbs were significantly higher $(P<0.05)$ in the Terai than in the Hill forest whereas dead wood and stumps and the soil organic carbon density were found to be not significantly different in these regions. Similarly, the highest amount of soil organic carbon (SOC) was found in the uppermost soil horizon in the forests of both the regions. These results revealed that the biomass carbon stock density was higher in the Terai S. robusta forest than in the Hill S. robusta forest. However, the SOC obtained was in inverse relation to that of the biomass carbon stock in both the ecological regions. It would not be biased if different ecological regions with similar forest types are intervened with different management strategies for having more carbon stocks and for the conservation of biodiversity in the days to come.
\end{abstract}

Key words: Biomass carbon, carbon stock density, ecological regions, Shorea robusta, soil organic carbon

$\mathrm{C}$ arbon stock is the absolute quantity of carbon held within a pool at a specified time whereas carbon sequestration is the process of increasing the carbon content of a carbon pool other than the atmosphere (FAO, 2011). In other words, carbon sequestration is understood as the removal of carbon from the atmosphere by storing it in the biosphere (IPCC, 2000). Forests play a profound role in reducing ambient carbon dioxide $\left(\mathrm{CO}_{2}\right)$ levels as they sequester 20-100 times more carbon per unit area than croplands (Brown and Pearce, 1994). Hence, vegetation and soils play role of viable sinks of atmospheric carbon and may significantly contribute mitigation of global climate change (Bajracharya et al., 1998; Lal, 2004). Biological sequestration of $\mathrm{CO}_{2}$ by forest has numerous benefits to other emission reduction technologies. Firstly, it is considered to be more effective than other carbon sequestration methods
(Banskota et al., 2007), and so it has become a least cost-solution in the world. Secondly, managing forests sustainably in tropical areas will greatly reduce carbon emissions as it is estimated that global deforestation alone accounts for about $17.4 \%$ (IPCC, 2007) of the global greenhouse gases emissions. Thirdly, there is a high potential for enhancing the carbon sequestration in the vegetation and soils of the Himalayan region through improved management of degraded lands (Upadhyay et al., 2005).

Soil organic carbon (SOC) stocks display a high spatial variability (Cannell et al., 1999). In fact, most of the studies concern only the topsoil (e.g. $0-30 \mathrm{~cm}$ ), although carbon sequestration or loss may also occur in deeper soil layers (Bird et al., 2002; Fontaine et al., 2007). SOC is an important index of soil quality because of its relationship to

REDD Implementation Centre, Kathmandu, Nepal. Email: pandeyhp123@gmail.com

${ }^{2}$ Nepal Herbs and Herbal Products Association, Kathmandu, Nepal 
crop productivity (Lal et al., 1997). In this regard, SOC sequestration has numerous economic as well as ecological implications in terms of trading carbon credits, improving quality of soil and water resources, and achieving food security.

Sal (Shorea robusta) is the most dominant species of the tropical and subtropical broadleaved forests of Nepal (Jackson, 1994). The Shorea robusta forest in Nepal is confined to the Hills and Terai ecological regions. It shares the highest tree volume i.e., 109.4 million $\mathrm{m}^{3}(28.2 \%$ of the total tree volume) (Amatya and Shrestha, 2010). S. robusta forests not only have higher economic value, but also serve as an important ecological benefit in the form of abating global warming and climate change through conserving atmospheric $\mathrm{CO}_{2}$ (Shrestha, 2008).

About 1.45 million households or 35 percent of the population of Nepal are involved in community-based forest management program through forming 17,685 Community Forest User Groups (CFUGs) who are managing 1,652,654 hectares of national forest handed over to them (DOF, 2015). Among these CFUGs, few of them have got reward for the carbon enhancement in their forests (Adhikari, 2016) as pilot programs. There is still a hope that the financial resources required to assist the developing countries in undertaking mitigation, and adaptation activities will become more and more significant in the future (UNFCCC, 2015) including Nepal. To ensure the carbon credit getting from one or other programs, it is very crucial to account carbon accumulation in forest to make the communities get benefited from carbon credits and biodiversity conservation. In spite of the protection of forests from local communities for 33 years, only a little attention has been paid so far to forest and soil inventories considering carbon stocks. Hence, amount of soil and biomass carbon sequestrated is unknown (Shrestha, 2008) in these forests. In Nepal, most of the studies have been conducted in forests for their tangible economic benefits whereas a very few studies have been done on intangible benefits such as carbon sequestration and biodiversity conservation. Information on carbon stocks in different forest ecosystems in Nepal is still lacking (Shrestha and Singh, 2008).

The participation in Reducing Emissions from Deforestation and Forest Degradation plus $($ REDD +$)$ mechanism has brighter prospect for
Nepal so as to generate carbon revenues as well as non-carbon benefits for the nation and her people where preliminary estimates show that REDD+ may bring between $\$ 20$-86 million per year to Nepal (UN-REDD, 2014). To provide somewhat base-line information regarding REDD + and to improve the carbon sink of the forests (REDDIC, 2015), this study could be a reference document since forest reference level is yet to be finalized in the national scenario. Therefore, the first step is to estimate the amount of carbon stocks in the forests of different conditions and types for getting credits from forest carbon in days to come. Hence, the present study aims to quantify and compare the carbon stock densities and to compare the soil carbon densities with at different depths in the community forests having dominance of $S$. robusta in the two different ecological regions of Nepal.

\section{Materials and methods}

\section{Study area}

Located between $27^{\circ} 15^{\prime}$ and $28^{\circ} 45^{\prime} \mathrm{N}$ latitude and between $84^{\circ} 27^{\prime}$ and $84^{\circ} 57^{\prime}$ E longitude, Gorkha District lies in the hilly region of Central Nepal. The total area of the district is $3,610 \mathrm{~km}^{2}$ with an altitudinal variation of $228-8,163 \mathrm{~m}$ above the mean sea level (amsl) (CBS, 2006). The district exhibits wide range of climate, from sub-tropical in the south to alpine in the north, with $23.1^{\circ} \mathrm{C}$ mean annual temperature and 1,500.20 mm average annual precipitation (DHM, 2015). Two community forests having the dominance of $S$. robusta were selected from Gorkha (in the Hills) and Chitwan (in the Terai) districts for the study (Fig. 1).

One of the two CFs selected for the purpose was Ghaledanda Ranakhola CF situated in the Bunkot Village Development Committee (VDC) of Gorkha District. The CF selected for the purpose lies in the sub-temperate region with an area of 181.63 ha and with 750-1,000 m altitudinal variation amsl (CBS, 2006). Most of the land is plain consisting of clayey loam soil; the soil is reddish under the $S$. robusta cover and blackish near the water holes. The CF is managed by a total of 459 households with 3,014 family members. The forest is consisted of medium-sized trees and dominated by S. robusta associated with Schima wallichii, Castanopsis indica and Lagerstroemia parviflora. 


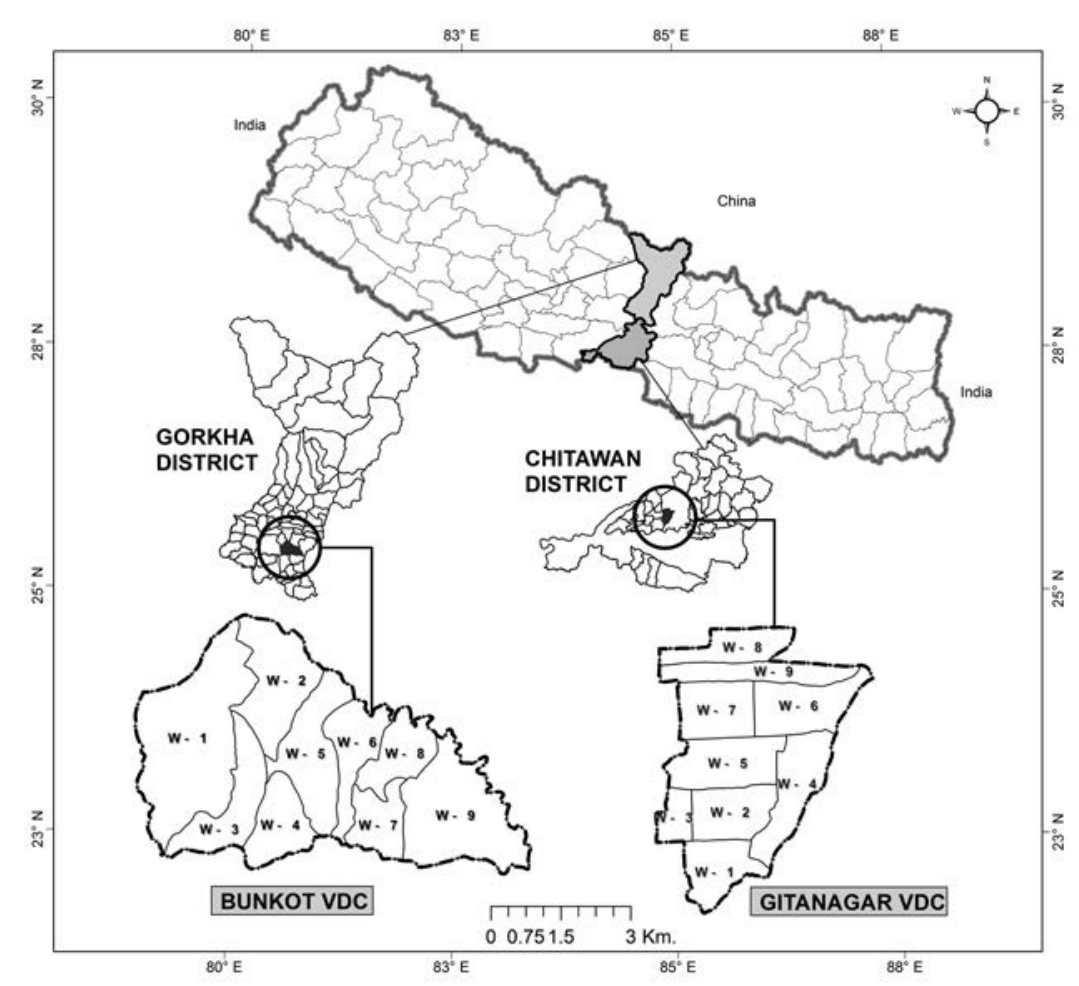

Fig. 1: Location map of two study areas in Chitwan and Gorkha districts of Nepal

Another CF selected for the purpose was Nawajyoti Buffer Zone CF situated in the Barandabar Corridor Forest of Geetanagar VDC in Chitwan District. Located between $27^{\circ} 21^{\prime} \mathrm{N}$ and $27^{\circ} 52^{\prime} \mathrm{N}$ latitude and between $83^{\circ} 54^{\prime} \mathrm{E}$ and $84^{\circ} 48^{\prime}$ E longitude, Chitwan District lies in the Inner-Terai region of Central Nepal; the total area of the district is $2,205.90 \mathrm{Km}^{2}$ with an altitudinal variation of $141 \mathrm{~m}$ to $1,947 \mathrm{~m}$ amsl (CBS, 2006). Moreover, subtropical type of climate prevails in the district with the yearly average temperature of $26^{\circ} \mathrm{C}$ and $1,512 \mathrm{~mm}$ average annual precipitation (DHM, 2015). The total area of the CF is 44.7 ha with an altitudinal variation of $175 \mathrm{~m}$ to $250 \mathrm{~m}$ amsl, and is managed and conserved by the Buffer Zone Community Forest User Group (BZCFUG) with a total of 302 households with 1,791 family members. Most of the land is plain consisting of clayey loam soil. The soil is reddish under the $S$. robusta cover and blackish near the water holes, similar to the one in the CF of Gorkha District. Likewise, there are yellowish fertile alluviums in some parts of the forest. The community forest is primarily dominated by $S$. robusta with a number of broad-leaved associate species including Sapium insigne and Bombax ceiba.

\section{Forest sampling and plot allocation}

For forest carbon inventory, systematic random sampling technique with $1 \%$ sampling intensity was used. For the purpose of plot allocation, both the forests were stratified on the basis of species composition, and then, on the basis of proportion allocation, concentric circular sample plots (CCSPs) were allocated randomly in each stratum. A total of 75 and 20 CCSPs with the radii of $8.92 \mathrm{~m}$ (for measuring trees and poles), 5.64 $\mathrm{m}$ (for measuring saplings), $1 \mathrm{~m}$ (for measuring seedlings) and $0.56 \mathrm{~m}$ (for taking the samples of the leaf litter, herbs, grass and soil) (Fig. 2) were laid out in the CFs of Gorkha and Chitwan Districts, respectively using the method described by ANSAB (2010).

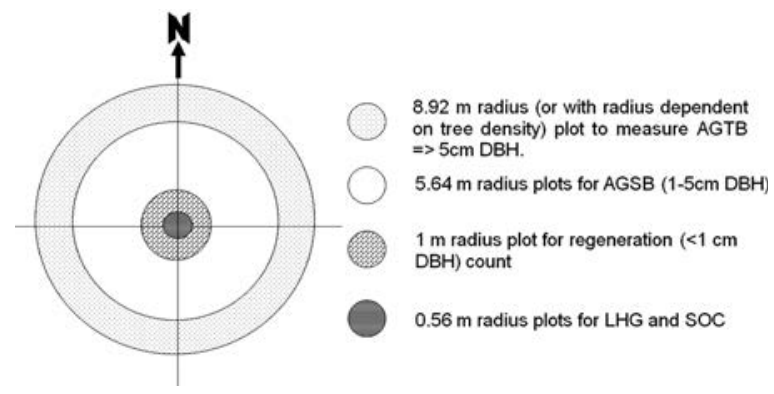

Fig. 2: Layout of a CCSP in the field

\section{Measurement of sample plots}

The diameter (at breast height) and height of all the trees, poles and saplings were measured using D-tapes and Suunto-clinometers, respectively 
while the seedlings were counted in the respective sample plots and all the herbaceous and woody vegetation inside the innermost $0.56 \mathrm{~m}$-radius plots were clipped and collected separately to take the fresh weights; the representative subsamples of $300 \mathrm{~m}$ of all the herbaceous plants, woody vegetation, leaf litters and grasses were taken to the soil laboratory of the Institute of Forestry (IOF), Pokhara for oven drying.

\section{Soil sample collection}

The soil samples from various depths $(0-20 \mathrm{~cm}$, $20-40 \mathrm{~cm}, 40-60 \mathrm{~cm}, 60-80 \mathrm{~cm}$ and $80-100 \mathrm{~cm}$ ) were collected using the methodology adopted by Awasthi et al. (2005). All the samples were bagged, labeled and sent to the soil laboratory for further analysis. The pit method was used for determining the bulk densities (Pearson et al., 2005) of the soil samples. Besides, several published and unpublished information were also collected from the secondary sources so as to fulfill the objectives of the study.

\section{Data analysis}

The biomass and carbon stock density from each site were analyzed using the allometric equation and the guidelines mentioned in "Forest Carbon Inventory Directives, 2011" prepared by the REDD Implementation Centre under the Ministry of Forests and Soil Conservation of the Government of Nepal (GoN, 2011).

The analysis of the soil samples were performed, adopting Walkey and Black Method (Jackson, 1958), in the Regional Soil Testing Laboratory of Pokhara. The aggregates of all the sources of carbon pools were added to obtain the total carbon stock. The carbon content was assumed to be $47 \%$ of dry biomass (IPCC, 2006 cited in GoN, 2011). The carbon stock density was calculated by summing the carbon stock densities of the individual carbon pools. In order to compare the carbon stock densities between the two ecological regions, t-tests were performed at $5 \%$ level of significance with the help of RStatistical Package Version 2.11.1 (RDCT, 2012). The graphs and tables were constructed using MS-Excel 2010.

\section{Results and discussion}

\section{Biomass carbon stock density}

The total carbon stock density of the forest vegetation including carbon in the trees, saplings, leaf litters, herbs and grass together with the dead wood and stumps was found to be $123.15 \mathrm{t} \mathrm{ha}^{-1}$ and $384.20 \mathrm{t} \mathrm{ha}^{-1}$ in the Shorea robuta forests of the Hills and the Terai, respectively. The above ground biomass carbon stock density comprised of $91 \%$ among the total biomass carbon stock density and the rest $9 \%$ belonging to the below ground (root) in both the ecological regions (Table 1). The bulk amount of carbon was found to be stored in the trees (including poles) followed by the leaf litters, herbs and grasses in both the regions. The t-test showed that there was significant difference $(P<0.05)$ in the carbon stock densities of these pools with respective to the ecological regions; the amount of carbon density was found to be significantly higher in the Terai forest than in the Hill forest. On the other hand, the dead wood and stump carbon stock density had no significant difference $(P>0.05)$ with respect to the ecological regions (Table 1). This signifies that same sorts of rules prevailing in the CFs that the users extract forest biomass one or other ways for fulfilling their daily needs.

Table 1: Biomass carbon stock densities in the study areas

\begin{tabular}{lrrrrrr}
\hline \multicolumn{1}{c}{ Carbon pools } & df & Hill CF & Terai CF & \multicolumn{1}{c}{ Mean } & P-value & Remarks \\
\hline Tree carbon density $\left(\mathrm{t} \mathrm{ha}^{-1}\right)$ & 114.004 & 115.22 & 359.69 & 237.455 & 0.000031 & $*$ \\
Sapling carbon density $\left(\mathrm{t} \mathrm{ha}^{-1}\right)$ & 36.298 & 0.28 & 0.39 & 0.335 & 0.002886 & $*$ \\
Herbs, grass and leaf litter $\left(\mathrm{t} \mathrm{ha}^{-1}\right)$ & 14.977 & 7.51 & 23.92 & 15.715 & 0.000016 & $*$ \\
Dead and stump carbon $\left(\mathrm{t} \mathrm{ha}^{-1}\right)$ & 32.151 & 0.14 & 0.20 & 0.170 & 0.135100 & \\
\hline Total of biomass carbon density & & $\mathbf{1 2 3 . 1 5}$ & $\mathbf{3 8 4 . 2 0}$ & $\mathbf{2 5 3 . 6 7 5}$ & & \\
Soil organic carbon $\left(\mathrm{t} \mathrm{ha}{ }^{-1}\right)$ & 5.678 & 111.39 & 95.09 & 103.240 & 0.558200 & \\
\hline Total carbon density & & $\mathbf{2 3 4 . 5 4}$ & $\mathbf{4 7 9 . 2 9}$ & $\mathbf{3 5 6 . 9 1 5}$ & & \\
\hline
\end{tabular}

Remarks: * = significant at $P<0.05$

Carbon on branches, leaves, and roots is included in their respective pools 


\section{Soil organic carbon}

The soil organic carbon (SOC) of Shorea robusta dominant $\mathrm{CF}$ was found to be higher in the Hill $S$. robusta forest $\left(111.4 \mathrm{tha}^{-1}\right)$ as compared to the one in the Terai S. robusta forest $\left(95.1 \mathrm{t} \mathrm{ha}^{-1}\right)$ (Table 1). The SOC contained in the topmost layer of soil (0-20 cm depth) in the Hill forest was found to be highest $\left(28.45 \mathrm{tha}^{-1}\right)$ and lowest $\left(16.9 \mathrm{tha}^{-1}\right)$ within the horizon of $60-80 \mathrm{~cm}$ depth (Fig. 3). Similarly, the SOC of the topmost layer of soil in the Terai forest was found to be highest (36.6 t $\left.\mathrm{ha}^{-1}\right)$ and lowest $\left(9.4 \mathrm{tha}^{-1}\right)$ within the end horizon of $80-100 \mathrm{~cm}$. Even though the cumulative value of the SOC is quite different in these community forests, there was no significant difference $(P>0.05)$ in storing organic carbon per unit area with respect to the ecological region (Table 1). The overall trend of the SOC showed the gradual decrease in carbon density with the increase in the soil depth in the Hill forest but there was no such significant trend in the Terai forest. However, the SOC density was found to have decreased from top to bottom with the increase in the soil depth in both the ecological regions (Fig. 3).

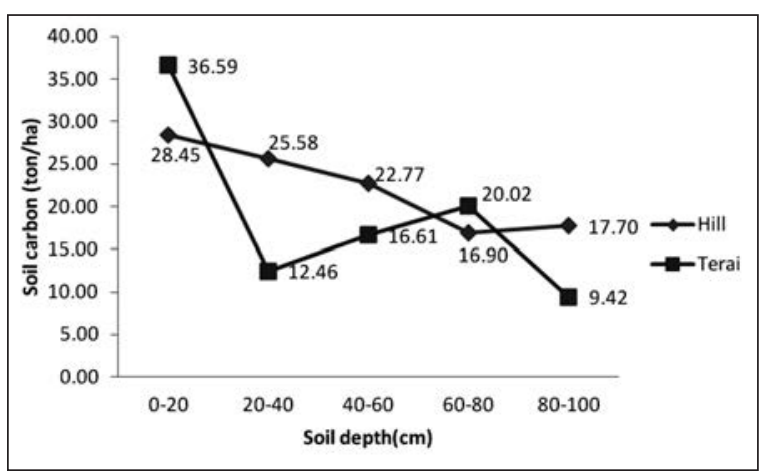

Fig. 3: Ecological region-wise SOC density at different soil depths

Although the trend line was found to have decreased drastically within the lowest horizon (80-100 cm depth), it was quite fluctuating within the middle horizons $(40-60 \mathrm{~cm}$ and $60-80 \mathrm{~cm}$ depths) in the Terai forest. This clearly indicates the seepage of SOC from the water holes in the $S$. robusta forest of the Terai ecological region. The main reason of difference in the SOC density is because of the difference in their bulk densities and the alluvial deposition in the soils of the Terai forest.

\section{Total carbon stock density}

The combined carbon stock density is the sum of biomass carbon stock density and the SOC stock density (Table 1). The total organic carbon in the Shorea robusta dominated forest was found to be $234.54 \mathrm{t} \mathrm{ha}^{-1}$ in the Hill S. robusta forest while it was $479.29 \mathrm{t} \mathrm{ha}^{-1}$ in the Terai S. robusta forest. A study conducted in the Kusumdanda Community Forest in Palpa District which is also situated in the Hill ecological region of Nepal, showed the carbon stock density in a Shorea robusta forest to be $186.95 \mathrm{t} \mathrm{ha}^{-1}$ (Nepal, 2006) and later, 235.95 $\mathrm{t} \mathrm{ha}^{-1}$ Shrestha (2008), which are almost similar to the results of this study conducted in the same ecological region. Another study conducted by ANSAB in the same CF (Ghaledanda Ranakhola CF in Gorkha) in 2011 estimated $211.184 \mathrm{t} \mathrm{ha}^{-1}$ of carbon stock whereas the SOC was calculated only up to $30 \mathrm{~cm}$ depths (ANSAB, 2011). The total organic carbon in the Terai (479.29 $\mathrm{t} \mathrm{ha}^{-}$ $\left.{ }^{1}\right)$ was found to be far greater than the average carbon stock of the tropical forests $(285.0 \mathrm{t}$ $\mathrm{ha}^{-1}$ ) of the world (Jina et al., 2008) although lower than the mean carbon stock estimation of the CF in Nepal (Acharya et al., 2009). This might be the reason of the availability of greater average diameter and height classes of the trees in the S. robusta dominated forest in the Terai as compared to the one in the Hills. The carbon stock density estimated in this study was higher than the average carbon stock in Nepalese forest $\left(161.1 \mathrm{t} \mathrm{ha}^{-1}\right)$ estimated by the Global Forest Resource Assessment Report of FAO (2006). The reason behind might be because of the use of the projected Forest Inventory data of 1994 by the FAO in its report.

However, the SOC in the Terai S. robusta forest was found to be lesser than that in the Hill $S$. robusta forest. Besides, the SOC content was also found to be low as compared to the biomass carbon content in the Terai forest whereas it was almost equal in the forest situated in the Hill region. In the case of SOC, it is highly dependent on bulk density, content of organic matters, type of soil and parent material since bulk density depends on several factors such as compaction, consolidation and amount of carbon present in soil (Morisada, et al., 2004 and Leifeld et al., 2004 cited in Ranabhat et al., 2008). Also, this clearly indicates the higher collection of leaf litter and plant residues by the community forest users from the Terai S. robusta forest, or the alluvial deposition in the soils of the Terai S. robusta forest, because of which the organic matter content in the soils is significantly decreased. 
In the case of the Hill S. robusta forest, both the above ground biomass and the SOC were found to possess $48 \%$ of carbon and the below-ground biomass (4\%) whereas in the case of the Terai $S$. robusta forest, more than two third of the carbon was found to be accumulated in the aboveground biomass $(72 \%)$ followed by SOC $(21 \%)$ and the least $(7 \%)$ in the below-ground biomass (Fig. 4). The above-ground biomass carbon in the Terai forest was almost 1.5 times more than that in the Hill forest whereas the SOC content was in reverse order as the Terai $S$. robusta forest contained less than half proportion of SOC than the Hill S. robusta forest.
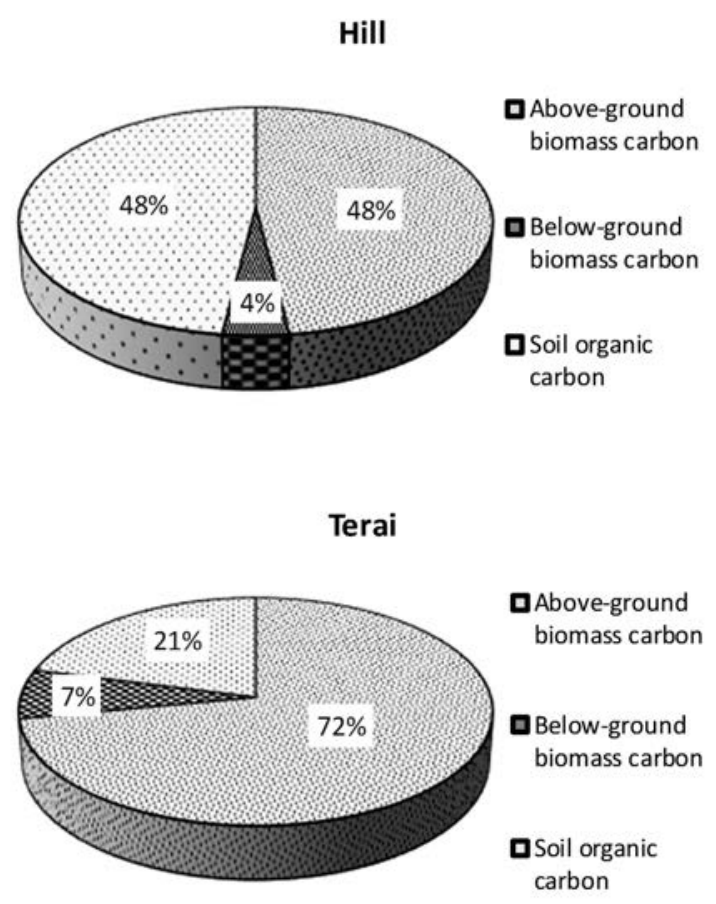

Fig. 4: Different carbon pools in the Hill and Terai $S$. robusta forests

\section{Conclusion}

The total biomass carbon density was found to be significantly higher in the Terai $S$. robusta dominated CF $\left(384.2 \mathrm{t} \mathrm{ha}^{-1}\right)$ than in the Hill $S$. robusta dominated CF (123.2 $\left.\mathrm{t} \mathrm{ha}^{-1}\right)$. However, the SOC in the Hill CF (111.4 t ha-1) was found to be more than the one in the Terai CF $(95.1 \mathrm{t}$ $\left.\mathrm{ha}^{-1}\right)$. It was found that the SOC decreased with the increase in soil-depth in both the ecological regions. The SOC contributed $48 \%$ of the total carbon pool in the Hill S. robusta forest whereas it accounted for $21 \%$ in the case of the Terai CF. Similarly, the total carbon stock density was found to be significantly higher in the Terai CF $\left(479.3 \mathrm{t} \mathrm{ha}^{-1}\right)$ than in the Hill CF $\left(234.5 \mathrm{t} \mathrm{ha}^{-1}\right)$. These results reveal that the communities have been conserving remarkable amount of carbon in their forests through proper forest management. However, replications of similar types of research on both the ecological regions are crucial to get valid inferences for the generalization of the result throughout the nation.

\section{Acknowledgements}

The authors are thankful to Eng. Kausal Raj Gnyawali for his GIS work and the anonymous reviewer for his/her constructive feedbacks in the preliminary version of the manuscript.

\section{References}

Acharya, K. P., Dangi, R. B., Tripathi, D. M., Bushley, B. R., Bhandary, R. R. and Bhattarai, B. 2009. Ready for REDD? Taking Stock of Experience, Opportunities and Challenges in Nepal. Nepal Foresters' Association, Kathmandu, Nepal.

Adhikari, S. 2016. Growing money from carbon. Kathmandu. http://communityredd.net cited on 16 February, 2016.

Amatya, S. M. and Shrestha, K. R., 2010. Nepal Forestry Handbook. Nepal Foresters' Association, Kathmandu, Nepal.

ANSAB. 2010. Forest Carbon Stock Measurement: Guidelines for measuring carbon stocks in community-managed forests. Asia Network for Sustainable Agriculture and Bio-resources (ANSAB), Federation of Community Forest User Groups and International Centre for Integrated Mountain Development, Kathmandu, Nepal.

ANSAB. 2011. Forest Carbon Stock of Community Forests in Three Watersheds (Ludikhola, Kayarkhola and Charnawati). Asia Network for Sustainable Agriculture and Bio-resources (ANSAB), Federation of Community Forest User Groups and International Centre for Integrated Mountain Development, Kathmandu, Nepal.

Awasthi, K. D., Singh, B. R. and Sitaula, B. K. 2005. Profile carbon and nutrient levels and management effect on soil quality indicators in the Mardi watershed of Nepal. Acta 
Agriculture Scandinavia Section B-Soil and Plant 3 (55): 192-204.

Bajracharya, R. M., Lal, R. and Kimble, J. M., 1998. Soil organic carbon distribution in aggregates and primary particle fractions as influenced by erosion phases and landscape position. In Soil Processes and the Carbon Cycle (eds) Lal R., Kimble J., Follett. R and Stewart B.A. CRC Press, Boca Raton, Florida, USA, 353-367.

Banskota, K., Karky, B. S. and Skutsch, M. 2007. Reducing Carbon Emissions through community-managed Forests in the Himalayas. International Centre for Integrated Mountain Development, Nepal. http://www.bookicimod.org accessed on 17 February, 2016.

Bird, S. B., Herrick, J. E., Wander, M. M. and Wright, S. F. 2002. Spatial heterogeneity of aggregate stability and soil carbon in semiarid range land. Environmental Pollution 11 (116): 445-455.

Brown, K. and Pearce, D. 1994. The economic value of non-timber benefits of tropical forests: carbon storage. In The Economics of Project Appraisal and the Environment; New Horizons in Environment Economics (ed) Weiss, J., and Elgar E. Aldershot Publishing, Chelttenham, UK, 102-123.

Cannell, M. G. R., Milne, R., Hargreaves, K. J., Brown, T. A. W., Cruickshank, M. M., Bradley, R. I., Spencer, T., Hope, D., Billett, M. F., Adger, W. N. and Subak, S. 1999. National inventories of terrestrial carbon sources and sinks: The UK experience. Climatic Change 26 (42): 505-530.

CBS. 2006. Environmental Statistics of Nepal. Central Bureau of Statistics (CBS), Kathmandu, Nepal.

DOF. 2015. Status of Community Forest Users' Groups. Department of Forests (DoF), Kathmandu, Nepal. http://dof.gov.np/dof_ community_forest_division/community_ forestry_dof accessed on 2 February, 2016.

DHM. 2015. Meteorological Data of Nepal. Department of Hydrology and Meteorology (DHM), Kathmandu, Nepal.

FAO. 2006. Global Forest Resource Assessment
Report. Food and Agriculture Organization of the United Nations (FAO), Rome, Italy.

FAO. 2011. FAO Glossary of Terms. Food and Agriculture Organization of the United Nations (FAO), Rome, Italy. http://www.fao. org/faoterm accessed on 2 February, 2016.

Fontaine, S., Barot, S., Barre, P., Bdioui, N., Mary, B. and Rumpel, C. 2007. Stability of organic carbon in deep soil layers controlled by fresh carbon supply. Nature 450: 277-280.

GoN. 2011. Forest Carbon Measurement Directives. (In Nepali version). The REDD Forestry and Climate Change Cell, Government of Nepal (GoN), Ministry of Forests and Soil Conservation, Kathmandu, Nepal.

IPCC. 2000. IPCC Special Report: Land Use, Land-Use Change, and Forestry (Summary for Policymakers). A Special Report of the Intergovernmental Panel on Climate Change. (IPCC), Geneva, Switzerland.

IPCC. 2007. Climate Change 2007: The Physical Science Basis - Summary for Policymakers. Intergovernmental Panel on Climate Change, Geneva, Switzerland.

Jackson, M. L. 1958. Soil Chemical Analysis. Prentice hall, New York, USA.

Jackson, J. K. 1994. Manual of Afforestation in Nepal (Volume I). $2^{\text {nd }}$ edition. Forest Research and Survey Center, Kathmandu, Nepal.

Jina, B. S., Sah, P., Bhatt, M. D. and Rawat, Y. S. 2008. Estimating carbon sequestration rates and total carbon stockpile in degraded and non-degraded sites of Oak and Pine forest of Kumaun Central Himalaya. Ecological Society, Nepal. Ecoprint 15: 75-81.

Lal, R., Kimble, J. M. and Follett, R. 1997. Land use and soil carbon pools in terrestrial ecosystems. In Management of Carbon Sequestration in Soils (eds) Lal, R., Kimble, J. M., Follett, R. CRC Press, New York, USA.

Lal, R. 2004. Soil carbon sequestration to mitigate climate change. Geoderma 123 (1-2): 1-22.

Nepal, S. 2006. A comparative study on carbon sequestration from two forest types in community forestry system (A case study 
from coniferous and broad-leaved forests in Palpa District). B.Sc. Thesis, Tribhuvan University, Institute of Forestry, Nepal.

Pearson, T. R., Brown, S. and Ravindranath, N. H. 2005. Integrating Carbon Benefit Estimates into GEF projects: Capacity Development and Adaptation Group Guidelines. Global Environment Facility, United Nations Development Program, New York, USA.

Ranabhat, S., Awasthi, K. D. and Malla, R. 2008. Carbon sequestration potential of Alnus nepalensis in the Mid-Hills of Nepal: a case study from Kaski District. Banko Janakari 18 (2): 3-9.

RDCT. 2012. R Statistical Packages. R Development Core Team (RDCT). http://rproject.org accessed on 2 January, 2012.

REDD-IC. 2015. REDD+ Strategy for Nepal (Draft). REDD Implementation Centre (REDD-IC), Ministry of Forests and Soil Conservation, Kathmandu, Nepal.

Shrestha, B. M. and Singh, B. R. 2008. Soil and vegetation carbon pools in a mountain watershed of Nepal. Nutrient Cycling in
Agroecosystems 81: 179-191.

Shrestha, B. P. 2008. An Analytical Study of Carbon Sequestration in Three Different Forest Types of Mid-Hills of Nepal. M.Sc. Thesis, Tribhuvan University, Institute of Forestry, Pokhara, Nepal.

UNFCCC. 2015. Paris COP 21: Information Hub. http://unfecc.int/focus/climate_finance/ items/7001.php accessed on 16 February, 2016.

Upadhyay, T. P., Sankhayan, P. L. and Solberg, B. 2005. A Review of carbon sequestration dynamics in the Himalayan region as a function of land use change and forest/soil degradation with special reference to Nepal. Agriculture, Ecosystems and Environment 105: 449-465.

UN-REDD. 2014. Understanding Drivers and Causes of Deforestation and Forest Degradation in Nepal: Potential Policies and Measures for REDD+. Discussion paper. http://www.tinyurl.com/nepal-drivers-redd accessed on 23 March, 2014. 